Кашина Г.С. кандидат педагогічних наук доцент кафедри освіти дорослих факультету перепідготовки та підвищення кваліфікації НПУ імені М.П. Драгоманова м. Київ

\title{
ТЕОРЕТИКО-МЕТОДОЛОГІЧНІ ОСНОВИ ВИКОРИСТАННЯ ДИСТАНЦЙНИХ ФОРМ НАВЧАННЯ У СИСТЕМІ ПІСЛЯДИПЛОМНОЇ ПЕДАГОГІЧНОЇ ОСВІТИ
}

У статті проаналізовано теоретичні та методичні аспекти використання дистаниійних форм навчання у системі післядипломної освіти вчителів технологій. Спираючись на матеріали державних стандартів, світовий та вітчизняний досвід впровадження дистанційних форм навчання сформульовано сучасне розуміння дистанційного навчання вчителів у системі післядипломної освіти.

Ключові слова. Дистанційні форми навчання; післядипломна освіта вчителів; методологічний підхід.

Постановка проблеми у загальному вигляді та її зв'язок із важливими науковими чи практичними завданнями Світові процеси глобалізації, становлення інформаційного суспільства спричинили кризу системи освіти. Сутність кризи української освіти полягає у невідповідності ii змісту та розвитку освітніх систем вимогам інформаційного суспільства.

Оскільки саме інформаційне суспільство характеризується високим рівнем інформаційних технологій, розвиненими інфраструктурами, які забезпечують розробку інформаційних ресурсів та можливості доступу до інформації, кардинальними змінами соціальних структур, розширенням сфери інформаційної діяльності. За таких умов інформатизація освітнього процесу означає зміну всієї освітньої системи, тобто орієнтацією іï на нову інформаційну культуру, підвищення доступності якісної освіти шляхом розвитку дистанційного навчання та засобів інформаційної підтримки навчального процесу сучасними інформаційними і телекомунікаційними технологіями.

Разом 3 тим впровадження дистанційного навчання в систему післядипломної освіти вчителів можна пояснити й тим, що консерватизм традиційних університетів став стримуючим фактором у системі підготовки та перекваліфікації фахівців в умовах інтенсивних змін у суспільстві.

Аналіз останніх досліджень і публікацій, в яких започатковано розв’язання даної проблеми і на які спирається автор, виділення невирішених раніше частин загальної проблеми, котрим присвячується дана стаття Дистанційне навчання широко використовується у світовій практиці та $є$ об’єктом зарубіжних досліджень - Т. Бейтс, Дж. Боат, Р. Гаррісон, Т. Еванс, Д. Кіген, А. Кей, Г. Кірслей, М. Мур, Х. Ператон, О. Петерс, Г. Рамбл, Д. Сьюарт, Б. Гольмберг, Д. Шейл, Е. Шілз та інші.

Українські дослідники почали працювати над дистанційним навчанням 3 1996 року. Вітчизняні педагогічні праці, в яких розкриваються питання теорії i практики дистанційного навчання, охоплюють таку тематику наукових 
досліджень: освіта й управління (В. Кремень, В. Луговий, В. Олійник та ін.); наукове забезпечення дистанційного навчання, проблеми та напрями досліджень цієї галузі (В. Биков, О. Довгялло, Ю. Дорошенко, М. Жалдак та ін.); організаційно-педагогічні основи дистанційної освіти за кордоном і в Україні, підходи до їх реалізації (Г. Атанов, Р.Гуревич, П. Дмитренко, Ю. Пасічник, О. Собаєва, П. Таланчук, М.Танась, В. Шейко, Б. Шуневич та ін.); психолого-педагогічні аспекти і технології створення дистанційного курсу (Г. Балл, В. Кухаренко, О.Рибалко, Н. Сиротенко, О. Сорока та ін.); перспективи дистанційного навчання у вищих навчальних закладах (ВН3) України та за кордоном (Г. Козлакова, К. Корсак, П. Стефаненко та ін.); моделювання і прогнозування його розвитку (В. Гондюл та ін.), контроль знань та їх оцінювання (І. Булах, В. Гондюл, О. Григор'єва, В. Дейнеко, О.Петращук); дистанційне навчання іноземних мов (В. Жулкевська, Н.Муліна, В. Свиридюк, П. Сердюков, О. Сорока); розроблення і використання мультимедіа і комп'ютерів при викладанні різних предметів, наприклад природничих дисциплін (П. Асоянц, О. Гон, В. Дейнеко, В. Редько, П. Сердюков, Г. Чекаль та ін.).

Формулювання цілей статті (постановка завдання). В межах статті проаналізувати основні теоретико-методичні підходи до використання дистанційних форм навчання та уточнити організацію дистанційного навчання вчителів у системі післядипломної освіти.

Виклад основного матеріалу дослідження 3 повним обгрунтуванням здобутих наукових результатів. В державній політиці України щодо інформатизації суспільства знайшло відображення і дистанційне навчання: в Законах України «Про Національну програму інформатизації» (2001р.) та «Про вищу освіту», в Указі Президента України «Про заходи щодо розвитку національної складової глобальної інформаційної мережі Інтернет та забезпечення широкого доступу до цієї мережі в Україні» (2000р.), Концепції розвитку дистанційної освіти в Україні (2000р.), «Положенні про дистанційне навчання» (2013 р.). У цих державних документах передбачено заходи, спрямовані на формування вчителя як носія ефективних форм взаємодії із суб'єктами педагогічного процесу.

Розвиток інформаційного суспільства, перехід від концепції «освіта на все життя» до концепції «освіта впродовж життя» зумовлює зміну парадигми освіти. Кожна парадигма формується залежно від елемента, який $\epsilon$ домінуючим у системі основних параметрів освіти як соціокультурного феномена. Такими елементами можуть бути уявлення про систему знань, умінь, навичок, необхідних людині в конкретну історичну епоху; усвідомлення типу культури і способів розвитку особистості у процесі іiі засвоєння; принципи кодування й передачі інформації; осмислення цінностей освіти в суспільстві; уявлення про місце і роль педагога як носія знань та культури в освітньому просторі; образ і місце людини в системі виховання, навчання та освіти [6, с. 30]. Традиційна освітня парадигма, що історично була застосована в Україні, зорієнтована на забезпечення ефективного функціонування людини в колективі, на виробництві, в суспільстві, тому 
незмінність форми навчання та кількісного складу класів у школі чи груп у вищих навчальних закладах приводить до того, що прагнення вдосконалити зміст чи методику викладання конкретних навчальних дисциплін не може суттєво вплинути на рівень їх засвоєння більшістю учнів.

Дистанційна форма навчання є однією із сучасних та ефективних форм навчання учителів під час підвищення кваліфікації чи перекваліфікації за іншими напрямами. Вона зумовлюється такими чинниками як процес комп'ютеризації навчальних закладів, зростання обсягу самостійної роботи студентів, а також перевагами дистанційного навчання: гнучкістю під час вибору місця й часу навчання, можливістю різноманітного подання навчальної інформації засобами мультимедіа, зростання активної ролі студента у навчанні тощо.

Необхідно враховувати також і особливості навчання вчителів у системі післядипломної освіти. Дослідники розглядають іï в двох вимірах: перший як процес професійного розвитку вчителів, тобто як мету і результат діяльності навчального закладу, а також у контексті залучення того, хто навчається до навчально-виховної діяльності [30, с. 184]. Така система навчання вчителів у системі післядипломної освіти відрізняється високим рівнем організації, має складну впорядковану структуру, об'єднану різноманітними зв'язками i взаємовідносинами, що є соціальними за своєю природою. Такій організації системі навчання притаманні динамічність, гнучкість, керованість, упорядкованість та внутрішня гармонійність компонентів.

За своєю сутністю дистанційне навчання відповідає гуманістичній парадигмі освіти, оскільки відповідає потребам професійного та духовного саморозвитку вчителя. Гуманістична парадигма апелює, доводить I. А. Зязюн, до індивідуалізації й диференціації навчання, до радості учіння, до процесу творчості $[17$, с. 217]. Проведений аналіз наукових джерел засвідчує, що в основу сучасної гуманістичної парадигми фахової підготовки вчителя у системі післядипломної освіти покладено такі філософські ідеї:

- суб'єкт педагогічного процесу — вільна і духовна особистість, якій притаманна потреба в саморозвитку і самовдосконаленні;

- цілі, зміст, форми і методи гуманістичної освіти зорієнтовані на особистість того, хто навчається, гармонізацію його розвитку;

- свобода як сукупність умов (зовнішніх або внутрішніх) сприяє гармонійному розгортанню та виявленню всебічних можливостей особистості [17, с. 21].

Теорія дистанційного навчання $є$ галуззю наукового знання, комплексом поглядів, уявлень, ідей, що спрямовані на усвідомлення та пояснення навчального процесу в системі дистанційного навчання. Обгрунтованою вважаємо класифікацію теорій дистанційного навчання, запропоновану американським науковцем Д. Кіганом, за якою розрізняють:

- теорії індустріалізації, які досліджують вплив технологій на процес навчання, що характерні суспільству на певному етапі його розвитку (O. Пітерс, М. Кампіон, Р. Едвадс, Н. Фарнес); 
- теорії взаємодії та комунікації, які акцентують увагу на ролі педагогічних технологій у досягненні результативності й інформаційнотехнологічному забезпеченні процесу навчання;

- теорії автономності, які базуються на розкритті автономності студентів на різних етапах навчання [48].

Розглянемо теорії, що $є$ теоретико-методологічними основами використання дистанційних форм у навчанні вчителя технологій у системі післядипломної освіти.

Важливою також $є$ теорія дистанційного навчання Джона Деніела, основою якої $є$ сконцентрованість на організації навчально-пізнавальної діяльності студента як системоутворюючого елемента процесу навчання на відстані. Дослідник виокремлює дві складові такої діяльності: «незалежну» та «інтерактивну». До «незалежної» відносить вивчення джерел, перегляд телепередач, проведення дослідів у домашніх умовах, виконання письмових завдань. «Інтерактивна» складова містить консультування студентів до та під час занять, перевірку i коментування виконаних завдань, організацію групових дискусій та літніх шкіл. Співвідношення між цими двома видами діяльності, наголошує Д. Деніел, є «вирішальним для системи дистанційного навчання», оскільки вони не тільки визначають процес навчання, а й суттєво впливають на адміністрування системи [40, с. 30].

Суттєву роль у розвитку теорії дистанційного навчання мають дослідження Отто Пітерса. Він розглядає дистанційне навчання як продукт індустріальної віхи розвитку суспільства та виокремлює три його періоди, кожному з яких властиві певні форми організації навчальної діяльності:

- доіндустріальний, у якому дистанційне навчання зіставляється із традиційним (аудиторні форми навчання);

- індустріальний, коли структура дистанційного навчання визначається принципами, що керують індустріалізацією процесу виробництва матеріальних благ, 3’являються нові технології (дистанційні форми навчання);

- постіндустріальний, для якого притаманні мережеві форми навчання.

О. Піттерс у своїх працях [53] доводить, що «в постіндустріальному суспільстві традиційна індустріальна модель дистанційного навчання вже не відповідає потребам студентів 3 їх специфічними очікуваннями та цінностями... така ситуація вимагає розробки нових моделей дистанційного навчання, які поєднували б тривалу групову роботу, нові засоби отримання інформації для самоосвіти i широкі контакти за допомогою засобів телекомунікацій... Основою нових моделей дистанційного навчання вважають самостійне керівництво процесом навчання та самонавчання студента, тобто діяльність студента буде більш автономною» [53, с. 57].

На основі дослідження праць О. Петерса щодо індустріальної теорії дистанційного навчання можна зробити такі висновки:

- структура дистанційного викладання значною мірою зумовлена принципами індустріалізації, зокрема таких, як: раціоналізація, розподіл праці та масове виробництво: процес навчання поступово трансформується 
завдяки підвищенню механізації та автоматизації, а це стимулює виникнення нових структурних характеристик навчальних закладів;

- розробка навчальних курсів дистанційного навчання відіграє таку ж роль, як і підготовча робота до початку виробничого процесу;

- ефективність навчального процесу у дистанційному навчанні залежить від його планування та організації;

- навчальні курси у дистанційному навчанні повинні бути максимально формалізовані, а очікувані результати стандартизовані;

- процес навчання носить цілеспрямований характер;

- у дистанційному навчанні суттєво змінюються функції викладача порівняно з традиційним навчанням;

- дистанційне навчання залежить від концентрації ресурсів та централізації адміністрування [54].

Проте індустріалізаційним теоріям дистанційного навчання бракує педагогічної складової на відміну від теорій другої групи - теоріях взаємодії та комунікації, яка активно розвивалася в 70-80-тих роках ХХ ст. Серед розробників теорії вчені: Бор’є Холмберг, Джон Баат, Джон Деніел, Девид Сьюарт та інші, які вважають форми і технології організації взаємодії та комунікації учасників навчального процесу ядром концепції дистанційного навчання.

Так, Джон Баат акцентував увагу на організації комунікацій студента i викладача, на місце та ролі контролю з боку викладача. За Дж. Баатом існує дві моделі взаємодії викладача і студента: жорстка та гнучка. Жорстка модель навчання побудована на строгому контролі викладача за процесом навчання студента, ієрархією навчального матеріалу, недостатня увага спілкуванню викладача та студента. Гнучкій моделі, навпаки, характерні нестрогий контроль за процесом навчання студента та надається перевага діалогу студента і викладача. В обох моделях залишаються незмінними такі функції викладача, як допомога в організації навчальної діяльності студента i підтримка мотивації його до навчання [38].

Розуміння навчання як процесу отримання знань окремим студентом складає сутність теорії шведського вченого Бор'є Холмберга. Його основним внеском у теорію дистанційної освіти є обгрунтування емпатійної теорії дистанційного навчання, положення щодо вирішення проблеми «самотності» студента у процесі дистанційного навчання через організацію керованого дидактичного спілкування, яке спрямоване на створення ілюзії «присутності викладача» (teaching presence). Б. Холмберг сформулював шість постулатів організації такого спілкування:

- відчуття особистої взаємодії викладача і студента сприяє отриманню задоволення від навчання та підвищення мотивації. Це відчуття задоволення може бути посилене завдяки якісним матеріалам для самостійного вивчення $\mathrm{i}$ двостороннього спілкування на відстані.

- саме інтелектуальне задоволення і мотивація сприяють досягненню цілей навчання й використанню відповідних форм та методів; 
- атмосфера, мова «дружньої бесіди» сприяє створенню відчуття реальної комунікації;

- інформація, яка передається під час розмови між студентом та викладачем в неофіційній формі, легко засвоюється і запам'ятовується;

- концепція «розмовного спілкування» успішно використовується 3 різними технологіями дистанційного навчання;

- для організованого навчання необхідне планування і керівництво, яке характеризується експліцитними та імпліцитними цільовими установками [45, c. 115-116].

Саме Б. Холмберг приділяв увагу питанням керованого комунікативного спілкування учасників навчального процесу і змісту навчання та вважав емпатійний підхід однією з головних складових дистанційного навчання. У процесі дистанційного навчання, доводив учений, актуалізуються емпатійні діалоги, які підтримують мотивацію до навчання і сприяють досягненню кращих результатів. За емпатійною теорією Б. Холмберга, кероване дидактичне спілкування містить діалог в режимі реального часу та $\epsilon$ змодельованим. Тому вчений розглядав дистанційне навчання як «доброзичливу розмову на основі якісно розроблених навчальних матеріалів, що призначені для самостійної роботи і спрямовані на стимулювання мотивації до опанування навчальним предметом» [46].

Однак недоліком такого навчання $€$ відсутність синхронного двостороннього зв'язку між викладачем та студентом, що може негативно вплинути на ефективність процесу навчання. Теорія емпатійного підходу в дистанційному навчанні Бор'є Холмберга отримала подальший розвиток у напрямку самостійного вибору навчальних програм, методів оцінки i контролю тими, хто навчається; формування освітнього середовища, яке стимулює активність студентів в організації та керуванні навчальним процесом; набуття нового досвіду, який не тільки забезпечує досягнення поставленої навчальної мети, а й готує студентів до життя, сприяє підвищенню якості їх життєвого рівня.

Саме емпатійна теорія дистанційного навчання відіграє важливу роль у навчанні вчителя у системі післядипломної освіти. В особистості вчителі 3 одного боку присутня індивідуальна якість, спрямованість особистості, що виявляється в готовності вчителя виявляти емоційне тепло, співпереживання, співчуття, сприяння учневі. Зрозуміло, що така душевність педагога допомагає йому розвивати душевність школяра, а з іншого боку необхідне співпереживання, розуміння ситуації [46]. Таким чином, емпатія є однією 3 необхідних характеристик особистості педагога.

Гуманістичний підхід у теорії дистанційного навчання, започаткований Ч. Ведемейєром та Б. Холмбергом, отримав подальший розвиток у теорії трансактної дистанції американського вченого Майкла Грехема Мура, що була названа «головна теорія дистанційного навчання» (О. Пітерс, Б. Холмберг) [54] та «центральна теорія для проектування курсів дистанційного навчання» (Р. Шіарер) [57, с. 220]. 
М. Мур, розробляючи теорію трансактивної дистанції, врахував висновки представників гуманістичної психології, зокрема К. Роджерса та Алана Тафа, щодо ідеї навчальної автономії, за якою в тих, хто навчається, добре розвинуте вміння розробляти власний навчальний план і знаходити джерела для вивчення й оцінювання своїх результатів [51].

За теорією М. Мура, трансакція у дистанційному навчанні є взаємодією викладача i студента у середовищі, характеризуються просторовою віддаленістю [54, с. 89-104]. Він розглядає «географічну дистанцію» як особливу (унікальну) характеристику дистанційного навчання, зважаючи на педагогічні підходи. Трансакційна дистанція — це, передусім, педагогічна, а не географічна категорія, яка вимагає «спеціальної організації та методів навчання» i передбачає зв'язок між трьома перемінними: структурою, діалогом, автономією [52, с. 3].

Структура дистанційного курсу розглядається М. Муром як певний ступінь свободи, яку надає студенту навчальна програма, у визначенні темпу, послідовності, мети та результатів, а також підходів до оцінювання. Діалог між викладачем та студентом М.Мур розглядає як результат аналізу комунікацій, набір повідомлень, якими обмінюються викладач та студенти. Такі повідомлення сприяють розумінню студентами навчального матеріалу i, як результат, формуванню системи знань.

Також важливим складником теорії трансакційної дистанції є автономія студента. М. Мур визначає автономію як «ступінь участі студента у визначенні й використанні цілей, процесу, засобів і контролю навчання [52, с. 13]. Американський учений довів, що навчальні програми можуть бути розроблені відповідно до ступеня самоуправління й автономії учня. Дослідник запропонував типологію програм дистанційного навчання, критерієм якої стала автономія студентів:

- програми, які передбачають високий рівень автономності студентів, тобто студенти мають свободу у прийнятті рішень, що вивчати (цілі), як вивчати (виконання), коли вивчати (планування), скільки вивчати (оцінювання);

- програми, що розраховані на студентів, які абсолютно не здатні приймати рішення щодо навчальної програми [52, с. 93-97].

Запропоновану М.Муром типологію навчальних програм називають «полюсною», оскільки в них визначається наявність чи відсутність автономії студентів. Водночас між цими «полюсами» знаходяться студенти, які мають тільки автономію у постановці цілей та виконання, автономію у постановці цілей і оцінювання результатів, або тільки автономію в постановці цілей, чи виконання, чи оцінювання.

Послідовником ідей М. Мура щодо діалогу, структури та автономії як трьох основних понять дистанційного навчання вважають О. Пітерса, який переконував у необхідності застосування гуманістичного підходу в дистанційному навчанні: «особистість не $є$ об'єктом педагогічного керівництва та примусового впливу, а є суб' єктом свого власного навчання й освіти». Коли студенти «усвідомлюють потребу в навчанні, формулюють 
навчальні цілі, добирають зміст, навчальну стратегію, засоби, додаткові особистісні та фізичні ресурси, використовують їх, самостійно організують, контролюють, перевіряють та оцінюють власне вивчення» [54, с. 48], вони автономні у педагогічному смислі.

Досвід показує, що теорії емпатії і трансакційної дистанції $є$ не лише теоріями дистанційного навчання. Це, передусім, теорії, що реалізують гуманістичний підхід i теорії гуманістичної парадигми. Такі теорії відповідають вимогам до навчання вчителя в системі післядипломної освіти, оскільки спрямовані на розвиток таких суб'єктивних якостей педагога, як автономність, незалежність, здатність до вибору, рефлексія, саморегуляція тощо, які по-різному можуть виявлятися у процесі дистанційного навчання. Ці теорії взаємно доповнюють і посилюють одна одну.

У дистанційному навчанні учителів в системі післядипломної світи необхідно застосувати ідеї теорії канадського професора Ренді Геррісона, який спираючись на висновки М. Мура, за основу теорії взяв двостороннє спілкування в режимі реального часу, трансакцію навчання та учіння, контроль навчання. Відповідно до теорії Р. Геррісона, модель трансакційного контролю містить забезпечення макроконтролю на рівні викладача, студента та змісту навчання. У середині макроконтролю функціонують трансакційні елементи мікроконтролю: уміння тих, хто навчається (їх здатності та мотивація навчання), підтримка (людські та технічні ресурси) та самостійність (можливість вибору) [46].

Всі розглянуті вище теорії дистанційного навчання, їх положення та висновки є актуальними для організації дистанційного навчання вчителів в системі післядипломної освіти. Проте необхідно зауважити, що теорія дистанційного навчання як вища, найрозвинутіша форма організації узагальненого достовірного наукового знання, представлена у вигляді системи, що описує, пояснює і передбачає функціонування певної сукупності складових об'єкта теорії, зокрема, дистанційного навчання. Структурними елементами теорії, поряд з предметом, методами та функціями, є терміни i поняття.

Аналізуючи наукові джерела необхідно виділити базові визначення дистанційного навчання. Зокрема, Б. Холмберг вважав, що термін «дистанційне навчання» $\epsilon$ найбільш оптимальним, оскільки «означає навчання на всіх рівнях і при цьому не вимагає постійного керівництва з боку наставників, їх присутності в одній аудиторії чи одному приміщенні 3 учнями. Водночас таке навчання передбачає можливості планування, адміністрування та консультування конкретного закладу» [47, с. 77]. В основу цього визначення покладено аспекти просторового та часового роз'єднання викладача та студента, а також планування і структурування навчального курсу.

О. Петерс розглядав «дистанційне навчання» як метод передачі знань, навичок, системи поглядів за допомогою використання технології роз'єднання та наукової організації праці, а також на основі активного застосування технічних засобів, особливо у процесі розробки високоякісних 
навчальних матеріалів. Цей метод дозволяє одночасно навчати велику кількість учнів, незалежно від місця проживання. Це - «індустріалізована» форма учіння та викладання» [54, с. 206]. Основу даного визначення становлять дві попередні характеристики Б. Холмберга та можливість використання технічних засобів.

Розробник теорії дистанційного навчання М. Мур визначав дистанційне навчання як «систему методів навчання, за якою викладання здійснюється окремо від навчально-пізнавальної діяльності студента (учіння)... так, що комунікації між викладачем та студентом можуть сприяти друковані, електронні, механічні та інші засоби» [52, с. 664]. Отже, у визначенні М. Мура можна виокремити три основні характеристики дистанційного навчання:

1. роз'єднання (просторове, часове) процесу викладання та учіння;

2. використання технічних засобів навчання;

3. можливість двостороннього зв'язку.

За М. Муром, викладання складається 3 двох етапів: за традиційним викладанням в аудиторії викладач готується до заняття окремо від студента, а сам процес навчання здійснює у присутності студентів; при дистанційному навчанні і підготовка i, власне, саме викладання здійснюється за відсутності студентів.

Визначення «дистанційного навчання» М. Мура в подальшому було доповнено Руне Флінком, який визначав дистанційне навчання як «систему навчання, в якій процес учіння відокремлено від процесу викладання. Студент працює один чи в групі,... може спілкуватися 3 консультантом за допомогою одного чи більше технічних засобів...; дистанційне навчання може поєднуватися $з$ іншими формами очних зустрічей» [51]. Це доповнене визначення є більш грунтовним, оскільки зосереджує увагу на можливостях групової співпраці викладача і студента.

Результати наукових досліджень дають можливість визначити інші характеристики дистанційного навчання. Д. Кіган актуалізує увагу на багатовимірності практичного застосування дистанційного навчання за допомогою типології, що базується на організаційних та дидактичних структурах [48]. Б. Баркер характеризує засоби доставки змісту навчального матеріалу [39].

Висновки. Отже, аналіз різних визначень поняття «дистанційне навчання» доводить відсутність єдиних підходів і свідчить про його полісемантичність i поліфункціональність. Так, дистанційне навчання розглядають як

- нову організацію освітнього процесу, що грунтується на принципі самостійного навчання студента. Середовище навчання характеризується тим, що учні майже завжди віддалені від викладача у просторі і (або) в часі, тоді як студенти мають нагоду в будь-який момент підтримувати діалог за допомогою засобів телекомунікації;

- новий спосіб реалізації процесу навчання, який грунтується на використанні сучасних інформаційних і телекомунікаційних технологій, що 
дозволяють здійснювати навчання на відстані безпосередньо, без особистого контакту між викладачем й особою, що навчається;

- новий ступінь заочного навчання, що забезпечується використанням інформаційних технологій, які грунтуються на використанні персональних комп'ютерів, відео-, аудіотехніки, супутникової та оптоволоконної техніки;

- організований за певними темами й навчальними дисциплінами навчальний процес, що передбачає активний обмін інформацією між учнями і викладачем, між учнями, та такий, що максимально використовує сучасні засоби нових інформаційних технологій (аудіовізуальні засоби, персональні комп'ютери, засоби телекомунікацій);

- форму, систему навчання, за якої взаємодія викладача й учня, учнів між собою здійснюється на відстані і відображає всі властиві навчальному процесу компоненти (цілі, зміст, методи, організаційні форми, засоби навчання), що реалізуються специфічними засобами Інтернет-технологій або іншими засобами, які передбачають інтерактивність;

- систематичне цілеспрямоване навчання, яке здійснюється на деякій відстані від місця розташування викладача. При цьому процеси викладання i вивчення розділені не тільки у просторі, а й у часі.

Проте всі вищезазначені визначення носять описовий характер, відображаючи лише одну або кілька сторін цього багатогранного явища. Тому означенням дистанційного навчання вчителів у системі післядипломної освіти є організацією освітнього процесу, що грунтується на принципі самостійного навчання, за якої взаємодія викладача й того, хто навчається, а також між собою здійснюється на відстані та відображає всі властиві навчальному процесу компоненти (цілі, зміст, методи, організаційні форми, засоби навчання), що реалізуються специфічними засобами Інтернеттехнологій або іншими засобами, які передбачають інтерактивність.

\section{ЛІТЕРАТУРА}

1. Ахаян А.А. К вопросу о технологии подготовки специалистов в области образования: информационно-образовательная среда педагогической магистратуры [Электронний ресурс] / А.А. Ахаян // Письма в Эмиссия. Оффлайн (The Emissia.Offline Letters): электронный научный журнал. — 2009. — Режим доступу : http://www. emissia.org/offline/2009/1362.htm

2. Ахаян А.А. Теория и практика становления дистанционной научно-образовательной деятельности педагогического университета на основе Internet-технологий: автореф. дис. на соискание научн. степени док. пед. наук : спец. 13.00.01 «Общая педагогика, история педагогики и образования» / А.А. Ахаян. - СПб., $2001-59$ с.

3. Биков В.Ю. Моделі організаційних систем відкритої освіти : монографія / В.Ю. Биков. - К. : Атіка, 2009. - 684 с.

4. Бордовская Н.В. Педагогика : Учебник для вузов / Н.В. Бордовская, А.А. Реан. - СПб. : Питер, 2000. - 304 c.

5. Бутиріна М.В. Теоретичні основи дистанційного навчання у галузі технологічної освіти України / М.В. Бутиріна, О.О. Бондаренко, М.Г. Погорєлов // Вісник Черні- гівського нац. пед. ун-ту імені Т.Г. Шевченка. — 2012. - Вип. 97. - С. 17-21.

6. Вища освіта України і Болонський процесс : навч. посіб. / За ред. В.Г. Кременя; Авт. кол.: М.Ф. Степко, Я.Я. Болюбаш, В.Д. Шинкарук та ін. - Тернопіль : Навч. кн. - Богдан, 2004. — 384 с.

7. Волженина Н.В. Организация самостоятельной работы студентов в процессе дистанционного обучения: учебное пособие / Н.В. Волженина. — Барнаул : Изд- во Алт. ун-та, 2008. — 59 с.

8. Гаевская Е.Г. К вопросу об истории развития теорий дистанционного обучения / Е.Г. Гаевская // Интернет и современное общество (IMS-2010) : Мат-лы XIII Все- российской объед. конф. — СПб., 2010. — C. 75-79. 
9. Гаевская Е.Г. Технологии сетевого дистанционного обучения : Учебное пособие / Е.Г. Гаевская. - СПб. : Ф-т филологии и искусств. - СПбГУ, 2007. - 55 с.

393 c.

10. Гончаренко С.У. Український педагогічний словник / С.У. Гончаренко. — К. : Ли- бідь, 1997. —

11. Гуревич Р.С. Інформаційно-телекомунікаційні технології в підготовці майбутнього фахівця // Неперервна професійна освіта: теорія і практика / Р.С. Гуревич. — К., 2002. — Вип. 4 (8). - С. 61-68.

12. Демкин В.П. Организация учебного процесса на основе технологий дистанционно- го обучения : Учеб.-метод. пособ. / В.П. Демкин, Г.В. Можаева. - Томск : Томский государственный университет, 2003. $-40 \mathrm{c}$.

13. Деражне Ю.Л. Педагогические основы открытого обучения / Ю.Л. Деражне. - М. : Сервиз, 1997. - 104 с. Егорова О.С. Теоретико-методические вопросы дистанционного обучения студентов / О.С. Егорова, Г.Г. Губина // Ярославский педагогический вестник. (Психоло- го-педагогические науки). - 2012. — T. II. - № 3. - C. 200-202.

14. Жевакіна Н.В. Професійні функції діяльності викладача-тьютора в умовах дис- танційного навчання / Н.В. Жевакіна, М.А. Семенов // Вісник ЛНУ імені Тараса Шевченка. — 2011. — № 5 (216). — С. $5-9$.

15. Информационные и коммуникационные технологии в дистанционном образовании : Специализированный учебный курс [пер. с англ.] / Майкл Г. Мур, Уэйн Ма- 2. 3. 4. 5. 6. 7. 8. 9. 10. 11.12 .13$. 14. 15. 16. 17. 18. 41 кинтош, Линда Блэк и др. - М. : Издательский дом «Обучение-Сервис», 2006.

16. Ковалева Т.М. Организация тьюторского сопровождения в образовательном учреждении: содержание, нормирование и стандартизация деятельности тьютора / Т.М. Ковалева // Стандарты деятельности тьютора: теория и практика : Материалы всерос. науч.-метод. сем. - М. : АПК и ППРО, 2009. $-208 \mathrm{c}$.

17. Кремень В.Г. Дистанційна освіта - перспективний шлях розв’язання сучасних проблем розвитку професійної освіти // Вісник академії дистанційної освіти. - 2003. — № 1. — С. 9.

18. Кухаренко В.П. Навчальний процес у масовому відкритому дистанційному курсі / B.M. Кухаренко // Теорія і практика управління соціальними системами : філо- софія, психологія, педагогіка, соціологія : щоквартальний наук.-практ. журнал. - 2012. - № 1. - С. 40-50.

19. Максимець С.М. Місце емпатії в професіограмі вчителя / С.М. Максимець // Пси- хологія : зб. наук. праць НПУ імені М.П. Драгоманова. — 1999. — Вип. 4(7). — С. 67- 72.

20. Неперервна професійна освіта: філософія, педагогічні парадигми, прогноз : Монографія / За ред. В.Г. Кременя. - К. : Наукова думка, 2003. - 853 с.

21. Овчарук О.В. Концептуальні підходи до застосування технологій відкритої освіти та дистанційного навчання у зарубіжних країнах та їх роль у процесах модернізації освіти [Електронний pecypc] / O.B. Овчарук. - Режим доступу : http://www.nbuv. gov.ua/ejournals/ITZN/em1/content/06oovemp.htm

22. Онушкин В.Г. Образование взрослых: междисциплинарный словарь терминологии / В.Г. Онушкин, Е.И. Огарев. - СПб. ; Воронеж : Рос. акад. образования. Ин-т образования взрослых. 1995. — 232 c.

23. Педагогические технологии дистанционного обучения: учеб. пособ. / под ред. Е.С. Полат. - М. : Изд. центр «Академия», 2006. - 400 с.

24. Полат Е.С. Теория и практика дистанционного обучения / Е.С. Полат, М.Ю. Бухар- кина, М.В. Моисеева. - М. : Издательський центр «Академия», 2004. - 416 с.

25. Рашевська Н.В. Хмарні технології дистанційного навчання у процесі навчання вищої математики

/ Н.В. Рашевська // Інформаційні технології в освіті. — 2013. — № 1. — С. 127-133.

26. Рябцев В.В. Модель дистанційного навчання у національному університеті оборони України /

В.В. Рябцев // Сучасні інформаційні технології у сфері безпеки та оборони. — № 1(4). — 2009. — С. 35-41.

27. Семиченко В.А. Пріоритети професійної підготовки: діяльнісний чи особистісний підхід / В.А.

Семиченко // Неперервна професійна освіта: проблеми, пошуки, перспективи : Монографія / За ред. I.А. Зязюна. - К., 2000. - С. 176-203.

28. Соколова І. В. Професійна підготовка майбутнього вчителя-філолога за двома спеціальностями: Монографія / За ред. С. О. Сисоєвої. - Маріуполь - Д. : АРТ- ПРЕС, 2008. — 400 с.

29. Стариченко Б. Е. Компьютерные технологии в тельных систем / Б. Е. Стариченко. Екатеринбург: УрГПУ, 1998. - 208 с.

30. Тавгень И. А. Дистанционное обучение: опыт, тонович Тавгень / Под ред. Ю. В. Позняка. — 2-е изд. испр. и доп. - Мн. : БГУ - 2003. - 227 с.

31. Толстова О. С. Гуманистический подход в обучения / О. С. Толстова // Вестник ТГПУ. - 2010. - Вып. 10 (100). - С. 34-38.

32. Хуторской А. В. Научно-педагогические предпосылки дистанционной педагогики / А. В. Хуторской // Открытое образование. - 2001. - № 2. - С. 30-35.

33. Шуневич Б. І. Розвиток дистанційного навчання у вищій школі країн Європи та Північної Америки: автореф. дис. на здобуття наук. ступеня канд. пед. наук: спец. 13.00.01 «Загальна педагогіка та історія педагогіки» / Б. І. Шуневич. - К., 2008. - 38 с. 
34. Шупта О. В. Дидактичні принципи дистанційного навчання / О. В. Шупта // Педа- гогічні науки. - 2011. — № 3 (61) - С. 131-135.

35. Щенников С. Модель открытого дистанционного образования взрослых / С. Щен- ников // Alma Mater: Вестник высшей школы. - 2002. - № 8. - С. 31-37. $527 \mathrm{c}$.

36. Щенников С. А. Открытое дистанционное образование / С. А. Щенников. - М. : Наука, 2002. —

37. Щенников С. А. Основы деятельности тьютора в зования: Специализированный учебный курс / Щенников С. А., Теслинов А. К. и др. - М. : Дрофа, 2006. - 591 с.

38. Baath J Distance students' learning - empirical findings and theoretical deliberations / J Baath // Distance Education. - 1982. - Vol. 3. - No 1. - P. 6-27.

39. Barker B. Broadening the Definition of Distance Education in Light of the New Tele- communications Technologies / Barker B., Frisbie A., Patrick K. // The American Jour- nal of Distance Education. — 1989. — Vol.3. 一 № 1. - P. 20-23.

40. Daniel J. S. Mega-Universities and Knowledge Media: Technology Strategies for Higher Education / John S Daniel. — London: Kogan Page, 1996. — 212 p.

41. El-Mowafy A. Blended learning in higher education: Current and future challenges in surveying education / Ahmed El-Mowafy, Michael Kuhn and To n y Snow // Issues in Educational Research. — 2013. — Vo 1 23 (2). - P. 132-150.

42. Flinck R Correspondence Education Combined with Systematic Telephone Tutoring: Report / Rune Flinck. - Washington D. C., 1978. - 139 p.

43. Garrison D Beyond independence in distance education. The concept of control / D. R. Garrison \& M Baynton // The American Journal of Distance Education. — 1987. — Vol.1. — № 3. — P. 3-15.

44. Henri F. tive learning through computer conferencing: The Najaden papers. - Berlin: Springer- Verlag, 1992. - P. 117-136.

45. Holmberg B. A Theory of Teaching-Learning Conversations / In Moore M. G. Hand- book of Distance Education. 2-ed. - New York: Routledge, 2007. - P. 69-75.

46. Holmberg B. Distance Education: A Survey and Bibliography. Nichols Publishing Cy, 1977. — 167 p.

Holmberg B. The Evolution, Principles and Practices of Distance Education. - Olden- burg: Bibliotheks-und Informationssystem der Universitдt Oldenburg, 2005. - $171 \mathrm{p}$.

47. Holmberg B. Theory and Practice of Distance Education / Borje Holmberg. — London; New Yo Keegan D. On Defining Distance Education / Desmond Keegan // Distance Educa- tion. — 1980. — № 1 (1). — P. $13-26$.

48. Keegan D. Reintegration of the teaching acts // Keegan D. (ed) Theoretical principles of distance education. - London; New York: Routledge, 1993. — P. 113-134.

49. Keegan D. Typology of Distance Teaching Systems / In: Harry K., John M. and Keegan D. (Eds.) Distance Education: New Perspectives. — London: Routledge, 1993. — P. 62- 76.

50. Knowles M. S. The modern practice of adult education: from pedagogy to andragogy / Malcolm Shepherd Knowles. — London: Cambridge Book Company, 1980. — 400 p.

51. Moore M. Editorial: Distance education theory / Michael G Moore // American Jour- nal of Distance Education. - 1991. - Vol. 5. - № 2. - Р. 1-6. 37. 38. 39. системе дистанционного обра- 40. 41. 42. 43.44 .45$. 46. 47. Computer conferencing and content analysis / In A. R. Kaye (Ed.), Collabora- 48. 49. — London : Kogan Page 50. 51. $\mathrm{r}$ k: Taylor \& Francis, 1994. - 264 p. 52. 53. 54. 55. 56.4357.

52. Moore M. G. Handbook of Distance Education / Michael G Moore. - 2 ed. - New Yo Moore M. Recent contributions to the theory of distance education / Michael G Moore // Open Learning. — 1990. — Vol.5. № 3. - P. 10-15. Moore M. Toward a // Journal of Higher Education. - 1973. - XLIV (12). — P. 661-679.

53. Peters O. Die didaktische Struktur des Fernunterrichts (The Didactical Structure of Distance Education). Untersuchungen zu einer industrialisierten Form des Lehrens und Lernens / Otto Peters. — Weinheim: Beltz. — 386 p.

54. Peters O. Learning and Teaching in Distance EducationB: Analyses and Interpreta- tions from an International Perspective / Otto Peters. — London: Kogan Page,1998. — 204 p.

55. Rogers C. A. Client Centered Therapy / C. A. Rogers. - Boston: Houghton Mifflin Company, 1965. — $225 \mathrm{p}$.

56. Shale Moore M. G. (Ed.) Contemporary Issues in American Distance Education. — Oxford: Pergamon, 1990. - P. 33-343. Shearer R. Instructional Design and the Technologies: An Overview / R. Shearer / In Moore M. G. Handbook of Distance Education. - Lawrence Erlbaum Assoc Incorpo- rated, 2007. — P. 219-232. To u g h stitute for Studies in Education, 1971. - 207 p. Wedemeyer C. A. Independent study / C. A. Wedemeyer / In R. Deighton (Ed.), Ency- clopedia of Education IV. — New York: McMillan, 1971. — P. 548-557.

Kashina Ganna PhD Associate THE SYSTEM OF POSTGRADUATE EDUCATION TEACHERS 
The article analyses the theoretical and methodological aspects of distance learning in the system of postgraduate education teachers who meet the requirements of the reform of public education and tendencies of world and national education. Based on materials state standards, the Law of Ukraine on education, international and domestic experience by formulating the modern understanding of the category "distance learning system of postgraduate education of teachers."

Analysis of different definitions of "distance learning" shows lack of common approaches and indicates its polisemantional and multifunctional. Thus, distance learning is considered as

- a new organization of educational process based on the principle of self-study;

- a new way to implement the learning process, which is based on the use of modern information and communication technologies to allow distance learning directly without personal contact between the teacher and the learner;

- a new distance learning degree, provided the use of information technology based on the use of personal computers, video, audio, fiber optic and satellite technology;

- organized by specific topics and academic disciplines learning process, involving active information exchange between students and teachers, among students;

- form a system of training in which the teacher and student interaction, students performed together at a distance and displays all the characteristic components of the learning process implemented by means of specific Internet technologies or other means that provide interactivity;

- systematic targeted training, which takes place at some distance from the location of the teacher. The process of teaching and learning are separated not only in space but also in time.

However, all of the above definitions are descriptive, displaying only one or more aspects of this multifaceted phenomenon. Therefore, the definition of remote training of teachers in the system of postgraduate education is a way of organizing the educational process based on the principle of selfstudy in which the interaction between teacher and of the student, and together carried out at a distance and displays all the characteristic learning process components (objectives, contents methods, organizational forms, teaching aids), implemented by means of specific Internet technologies or other means that provide interactivity.

Keywords. Distance learning; continuing education teachers; methodological approach. 